\title{
BURSA İLİNDE SÜRDÜRÜLEBİLİR KENTSEL SU YÖNETİMİ
}

\author{
Simge SOLAK* \\ Melike YALILI KILIÇ* \\ Seval Kutlu AKAL SOLMAZ
}

Alınma: 24.09.2018; düzeltme: 04.02.2019; kabul: 12.02.2019

Öz: Günümüzde teknolojinin hızla gelişmesi, yaşam kalite standartlarının yükselmesine katkı sağlamakla birlikte, teknolojik gelişmelerin etkisiyle nüfus da hızla artmaktadır. Bu durum, sinırlı olan su kaynaklarının amacına uygun kullanılmaması ve bilinçsizce kirletilmesi ile üzerindeki baskıyı giderek arttırmaktadır. Mevcut durumun iyileştirilmesi amacıyla, çevresel, sosyal ve ekonomik unsurları içeren plan ve projelerin yetkili kurumlarca hazırlanması ve uygulanması gerekmektedir. Bursa ilinin su kaynaklarının mevcut durumunun değerlendirildiği bu çalışmada, öncelikle su ve su kullanımının önemi vurgulanmıştır. Türkiye'nin 4. büyük ili olan ve 2017 yılı itibariyle 2936803 kişi nüfusa sahip Bursa'nın su ihtiyacı yüzeysel sular, yeraltı suları ve pınarlar olmak üzere üç ana kaynaktan karşılanmaktadır. Kaynakların kapasiteleri sirasiyla 1063,275 ve $17,4 \mathrm{hm}^{3} / \mathrm{y}$ l olup, bu kapasitelerin ilin su ihtiyacinı karşılar seviyede olduğu görülmektedir. Kentsel su yönetimi kavramı için su kaynaklarının sürdürülebilirliğinin temin edilmesine yönelik ilin çevre ve çevre koruma alanında hizmet veren 8 kamu kurumunda görevli 200 yöneticiye anket çalışması uygulanmıştır. Doğru ve bilinçli su kullanımı için farkındalık yaratılmasının hedeflendiği bu çalışma neticesinde, mevcut ve planlanan su kaynaklarında sürdürülebilir kentsel su yönetiminin kurumsal düzeyde uygulanabilirliğine dair bazı çözüm önerileri ortaya konmuştur.

Anahtar Kelimeler: Su kaynakları, kentsel su yönetimi, kamu kurumları, sürdürülebilir su kullanımı

\section{Sustainable Urban Water Management in Bursa}

Abstract: Nowadays, the rapid development of technology has contributed to the rise of living standards. However, along with technological improvements, the population is also rapidly increasing. This situation is use of limited water resources for its intended purpose and unconscious pollution, increasing the pressure on it. In order to improve the existing situation, pland and projects involving enviromental, social and economic elements need to be prepared and implemented by the authorized institutions. In this study where the current situation of water resources of Bursa province is evaluated, the importance of water and water use emphasized. Bursa, which is the 4th largest city of Turkey and has a population of 2 936803 as of 2017, is provided from three main sources as surface waters, ground waters, and springs. The capacities of resources are 1063, 275 and $17.4 \mathrm{hm}^{3} / y e a r$, and these capacities are seen to be in the level that meets the need of water. The concept of urban water management for the sustainability of water resources, 200 manager surveys were conducted in 8 public institutions providing services in the field of environmental protection and environmental protection. We aimed to create awareness for correct and

\footnotetext{
* Bursa Uludağ Üniversitesi, Mühendislik Fakültesi, Çevre Mühendisliği Bölümü, 16059, Nilüfer, Bursa İletişim Yazarı: Melike YALILI KILIÇ(myalili@uludag.edu.tr)

"Bu makale 10-12 Ekim 2017 tarihleri arasında U.Ü. Asım Kocabıyık M.Y.O. Yerleşkesi/Gemlik de düzenlenen Ulusal Çevre, Deniz ve Kıyı Kirliliği Sempozyumu'nda (UCEDKKS-2017 Bursa) sunulmuş ve yeniden değerlendirilmiştir."
} 
conscious water use. As a result of this study, some solutions have been proposed for institutional applicability of sustainable urban water management in existing and planned water resources.

Key words: Water resources, urban water management, public institutions, sustainable water use

\section{GİRIŞ}

Nüfus, hızlı kentleşme, endüstriyel ve tarımsal faaliyetlerin artması gibi nedenler su ihtiyacının daha fazla artmasına, bu da su kaynaklarının hem aşırı miktarda tüketilmesine hem de kirletilmesine neden olmaktadır (Yalılı Kılıç ve diğ., 2006; Yalılı Kılıç ve diğ., 2013). Bu durum su kaynaklarının bilinçsiz kullanımından kullanılamaz hale gelmesine kadar çeşitli sorunlara yol açmaktadır (Meriç, 2004; Teksoy ve diğ., 2017). Dünyada mevcut olan suyun miktarı 141 milyar $\mathrm{m}^{3}$ olmasına rağmen, kullanılabilir suların miktarı $7600 \mathrm{~m}^{3} /$ kişi-yıl, Türkiye'de ise bu rakamın $1430 \mathrm{~m}^{3} /$ kişi-yıl olduğu görülmektedir (Yalılı K1lıç ve Akal Solmaz, 2016). Nüfus artışı ve insan ömrünün uzaması faktörleri dikkate alındığında, 2025 yılında kişi başına $1100 \mathrm{~m}^{3}$ suyun düşeceği beklenmektedir (Akal Solmaz ve diğ., 2011; Yalılı K1lıç ve di ̌̆., 2011). Kullanılabilir su miktarının giderek azalacak olması, su kaynaklarının korunması ve sürdürülebilir su kullanımı hedeflerine sahip sürdürülebilir kentsel su yönetimi kavramının uygulanmas1 gerektiğini ortaya koymaktadır (Corcoles ve diğ., 2010; Petroulias ve diğ., 2016; Ross, 2017). Bu yönetim kavramına göre, kirlenmiş bir su kaynağının iyileştirilmesi ya da oluşan atıksuların arıtılması gibi alternatifler yerine önceliğin su kaynaklarının kirlilikten korunmas1 olmalıdır (Rygaard ve diğ,, 2014; Araujo ve diğ, 2015). Suyun kalite ve miktar analizleri yapılarak, kirletici faktörler belirlenmeli, su kaynaklarına uygun önlemlerin alındığ stratejiler uygulanmalıdır (Kolokytha, 2002; Gao ve diğ., 2014). Sürdürülebilir kentsel su yönetiminin doğru şekilde uygulanabilmesi için çevresel, ekonomik ve sosyal unsurların birbiriyle bütünleştirilmesi, mevcut plan ve projelerdeki eksikliklerin göz önüne alınarak hareket edilmesi gerekmektedir. Eksikliklerin doğru raporlanabilmesi için su kaynakları izlenmeli ve planlamanın zayıf noktaları ve firsatları belirlenmelidir. $\mathrm{Bu}$ analizlerin oluşturulması ise planları hazırlayan ve uygulayan kurumlar sorumluluğundadır ( $\mathrm{Hu}$ ve diğ., 2014; Araujo ve diğ., 2015). Bu kurumlar tarafından konunun sürdürülebilir kentsel su yönetimi kapsamında değerlendirilmesi için çevresel, sosyal ve ekonomik unsurlarla birlikte ele alınması gerekmektedir (Gao ve diğ., 2014; Hoek ve diğ., 2016).

Güney Marmara Bölgesi'nde yer alan Bursa ili gelişmiş sanayisi ve ekonomik özellikleri ile önemli bir konuma sahiptir. Yüzeysel ve yeraltı suları bakımından oldukça zengin bir bölgede bulunan Bursa için Evliya Çelebi Seyahatname isimli eserinde "...Velhasıl Bursa sudan ibarettir." diyerek şehrin su kaynaklarının bolluğuna değinmiştir (Yalılı Kılıç ve diğ., 2013; Yalılı Kılıç ve Akal Solmaz, 2016). Türkiye'nin 4. büyük ili olan Bursa'nın nüfusu 2017 yılı itibariyle 2936803 kişidir. İl nüfusunun 2025 yılında da yaklaşık 3324559 kişi olması beklenmektedir (Anonim, 2018). Artan nüfusa bağlı olarak su ihtiyacının da artması, mevcut ve ileriye yönelik karar ve planlamanın geliştirilmesi gerektiğini göstermektedir. Bu bağlamda bu çalışma ile ilin mevcut su kaynakları kapsamlı olarak değerlendirilmiş, su kaynaklarında sürdürülebilir su kullanımına yönelik görüşlerin elde edilebilmesi için Bursa'da çevre ve çevre koruma alanında hizmet veren 8 kamu kurumunda görevli 200 yöneticiye anket çalışması uygulanmıştır. Çalışmanın neticesinde, kentsel su yönetimi kavramının uygulanabilirliği için gerekli bazı çözüm önerileri yapılmıştır.

\section{BURSA İLININ SU KAYNAKLARI}

Marmara Denizi'ne 115 km kıyısı bulunan Bursa ili su kaynakları bakımından oldukça zengin olup, ilin su ihtiyacı 3 ana kaynaktan sağlanmaktadır. Bunlar; yüzeysel su kaynakları, yeraltı su kaynakları ve pınarlardır. Yüzeysel su kaynakları, akarsular, doğal göller, baraj ve rezervuarları kapsamaktadır (Anonim, 2015; Yalılı Kılıç ve Akal Solmaz, 2016). 


\subsection{Yüzeysel Su Kaynakları}

Bursa'nın en önemli akarsuyu $680 \mathrm{~km}^{2}$ su toplama havzası alanıyla Nilüfer Çayı'dır. Uludağ'ın güney yamaçlarından yeryüzüne çıkan çay, kendisini besleyen dereler ile su potansiyelini faydalanılabilir bir boyuta çıkartmaktadır (Şekil 1). Bu derelerden Deliçay deresi yaklaşık $203 \mathrm{~km}$ uzunluğa sahip yılda $85 \mathrm{hm}^{3}$ kapasitesi ile Nilüfer Çayı'nın mevcut su potansiyelini \%40 civarında arttırmaktadır. Nilüfer Çayı, Uluabat mansabında Susurluk Çayı'na karıştıktan sonra Karacabey Boğazı'ndan Marmara Denizi'ne ulaşmaktadır.

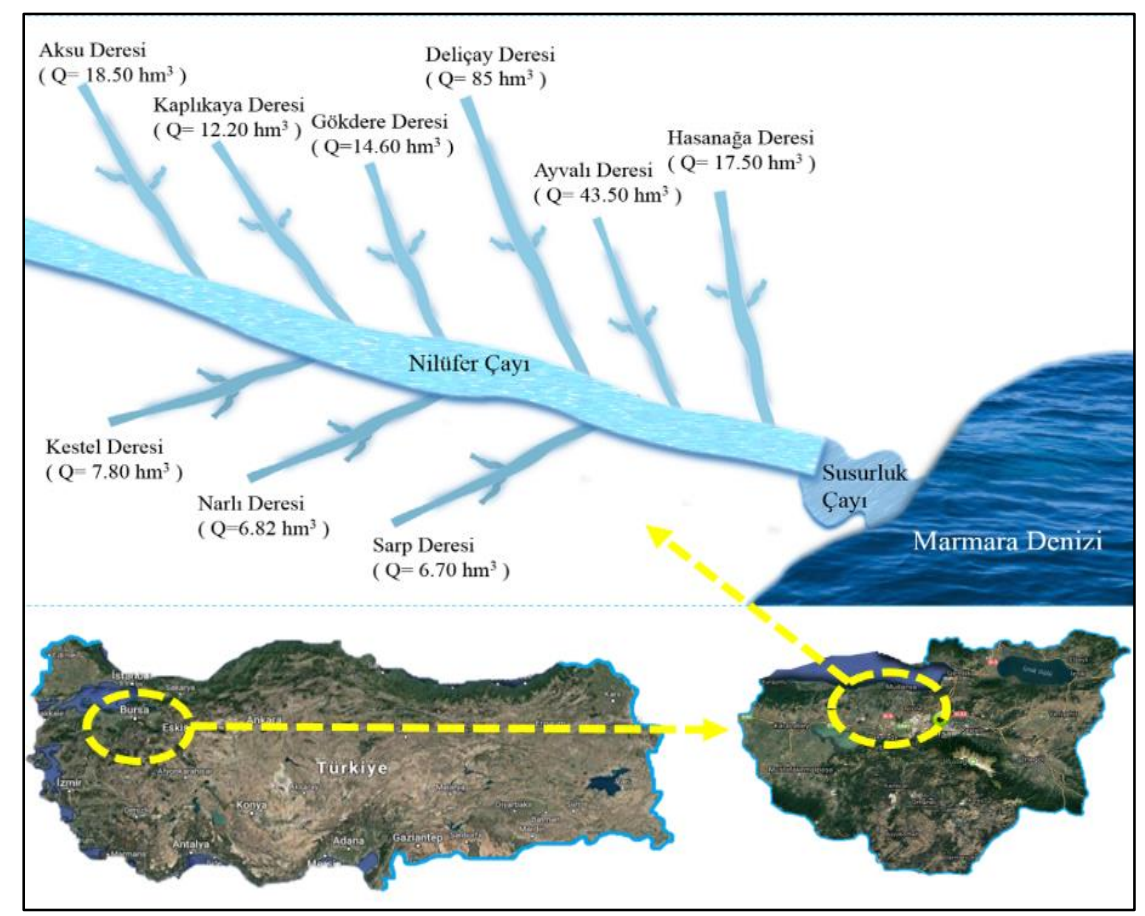

Şekil 1:

Nilüfer Çayı'nın alt havzası

Nilüfer Çayı üzerinde Doğancı ve Nilüfer Barajları bulunmaktadır. Bu barajlardan 1983 yılında hizmete alınan Doğancı Baraj1 $110 \mathrm{hm}^{3} / \mathrm{y} 1 \mathrm{l} \mathrm{kapasiteli} \mathrm{olup,} 2007$ yılında hizmete alınan Nilüfer Barajı'nın kapasitesi ise $60 \mathrm{hm}^{3} / \mathrm{y}$ ldır (Anonim, 2016b). İlin kullanım amaçlarına yönelik su ihtiyaçlarının karşılandığı barajlar ve yıllık kapasiteleri Tablo 1'de verilmiştir. Bursa ilinde mevcut su kaynakları içerisinde su potansiyeli yüksek olan bir diğer su kaynağı Orhaneli Çayı olup, 2008 yılında hizmete alınan Çınarcık Barajı ile $145 \mathrm{hm}^{3} / \mathrm{y} 1 \mathrm{l}$ su elde edilmektedir (Tablo 1).

Tablo 1. Bursa ilinde su ihtiyaçlarının karşılandığı barajlar (Anonim, 2016b)

\begin{tabular}{|c|c|c|c|}
\hline Baraj & $\begin{array}{c}\text { Endüstriyel } \\
\left(\mathbf{h m}^{3} / \mathbf{y l l}\right)\end{array}$ & $\begin{array}{c}\text { Sulama } \\
\left(\mathbf{h m}^{3} / \mathbf{y l l}\right)\end{array}$ & $\begin{array}{c}\text { Icçme Suyu } \\
\left(\mathbf{h m}^{3} / \mathbf{y l l}\right)\end{array}$ \\
\hline Doğanc1 & - & - & 110 \\
\hline Nilüfer & - & - & 60 \\
\hline Gölbaş1 & - & 25 & 57 \\
\hline Çınarcık & 75 & - & 70 \\
\hline Demirtaş & 1 & 8,54 & - \\
\hline
\end{tabular}


Uluabat ve İznik gölleri de ilin su potansiyeli açısından önemli su kaynakları içerisinde yer almaktadır. Uluabat Gölü, ortalama derinliği $2,5 \mathrm{~m}$ olan bir tatlı su gölüdür. Küçük dereler ve tarımsal drenaj suları ile beslenmekte olup, en önemli su kaynağı Mustafakemalpaşa Çayı'dır. Ayrıca Uluabat Gölü Ramsar Sözleşmesi kapsamında yer almaktadır. Yıllara ve mevsimlere bağlı olarak değişiklik gösteren gölün fazla suları, batısında kalan Uluabat Deresi ile Susurluk Çayı'na aktarılmakta ve Marmara Denizi'ne ulaşmaktadır. İznik Gölü ise Marmara bölgesinin en büyük, tektonik tatlı su gölü olarak bilinmektedir. İznik Gölü, Karasu ve Sölöz dereleri ile beslenmektedir. Göl özellikle tarımsal sulama ve endüstriyel su alanları için önem teşkil etmektedir (Anonim, 2016a).

\subsection{Yeraltı Su Kaynakları}

Bursa Ovası konum olarak yeraltı suyu ve pınar kapasitesi bakımından zengin olup, su temini sığ kuyulardan yapılmaktadır. Suların kimyasal olarak içilebilir formda olması ile içme suyu dışında endüstriyel alanda kullanımı da söz konusudur. İlin yeraltı suyu kapasitesi yıllık ortalama $317 \mathrm{hm}^{3}$ olup, bu miktarın yaklaşık $275 \mathrm{hm}^{3}$ 'ü su temini amacıyla kullanılmaktadır (Anonim, 2017a). Bu durum Şekil 2'de görülmektedir.

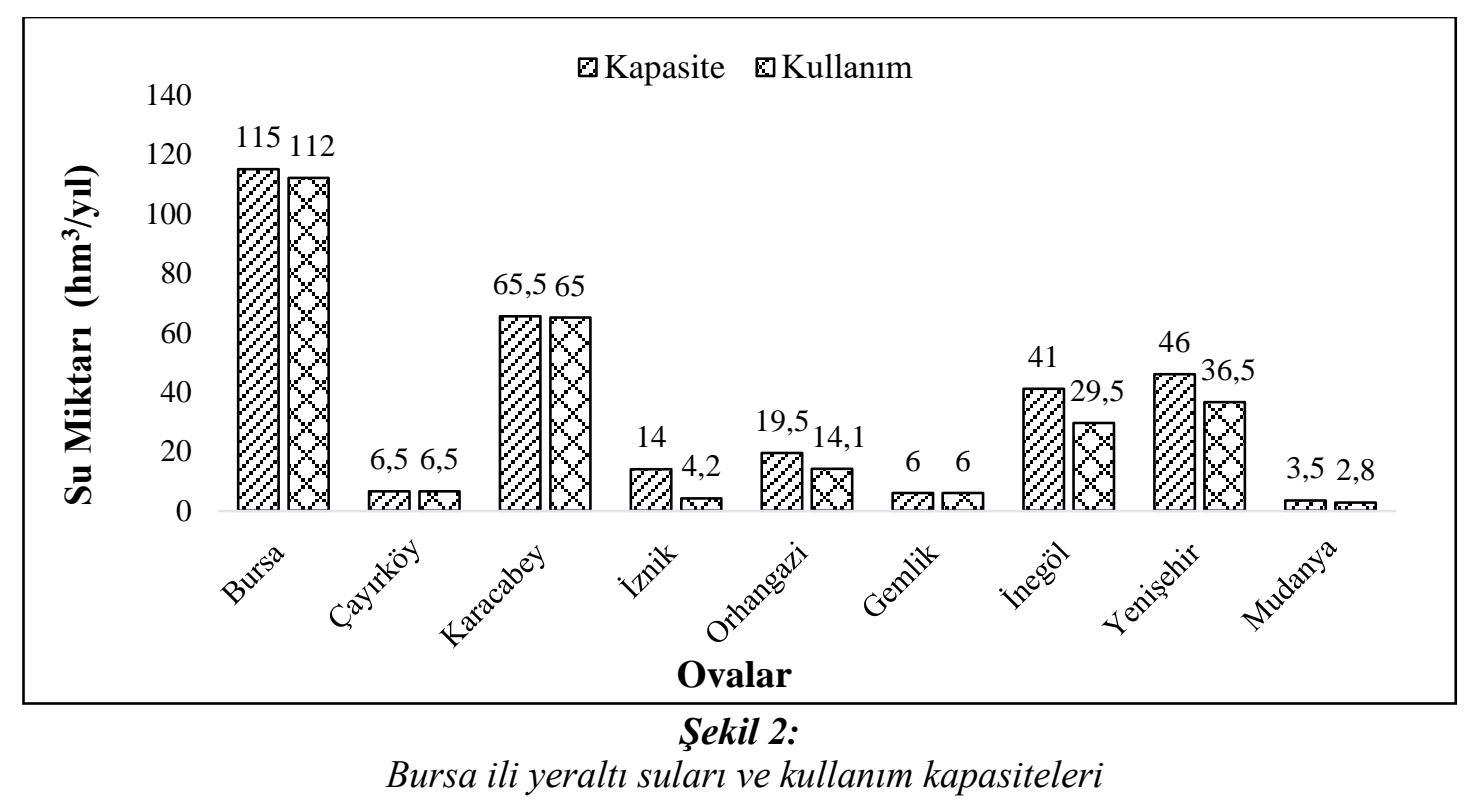

\subsection{Su Kaynaklarının Kullanım Durumu}

Bursa ilinin su ihtiyacı yüzeysel sular, yeraltı suları ve pınarlar olarak üç ana kaynaktan sağlanmaktadır. İlin yüzeysel su kaynaklarının toplam kapasitesi yaklaşık $1063 \mathrm{hm}^{3} /$ yıl, yeraltı sularının kapasitesi ise yaklaşık olarak $275 \mathrm{hm}^{3} / \mathrm{y}$ 1dır (Anonim, 2016b). Pınarlardan elde edilen su miktarı 2017 yılı itibariyle 17,4 hm $\mathrm{hm}^{3} / \mathrm{y}$ l olup, ilin su ihtiyacının yaklaşı \% $\% 15$ 'ni karşılamaktadır (Anonim, 2017c). Bursa'nın mevcut su kaynakları içme-kullanma suyu, sulama ve endüstri gibi faaliyetlerde kullanılmaktadır. Doğancı Barajı'ndan içme suyuna verilen miktarın $110 \mathrm{hm}^{3}$, Nilüfer Barajı'ndan içme suyuna verilen miktarın $60 \mathrm{hm}^{3}$, Gölbaşı Barajı'ndan sulamaya verilen miktarın $25 \mathrm{hm}^{3}$, Demirtaş Barajı'ndan sulamaya verilen miktarın $8,5 \mathrm{hm}^{3}$, endüstriye verilen miktarın ise $1 \mathrm{hm}^{3}$ olduğu bilinmektedir (Tablo 1). Bursa'nın su üretim, tüketim ve kullanımdan kaynaklanan kayıp oranları sırasıyla Şekil 3-5'te gösterilmiştir (Anonim, 2017a). 


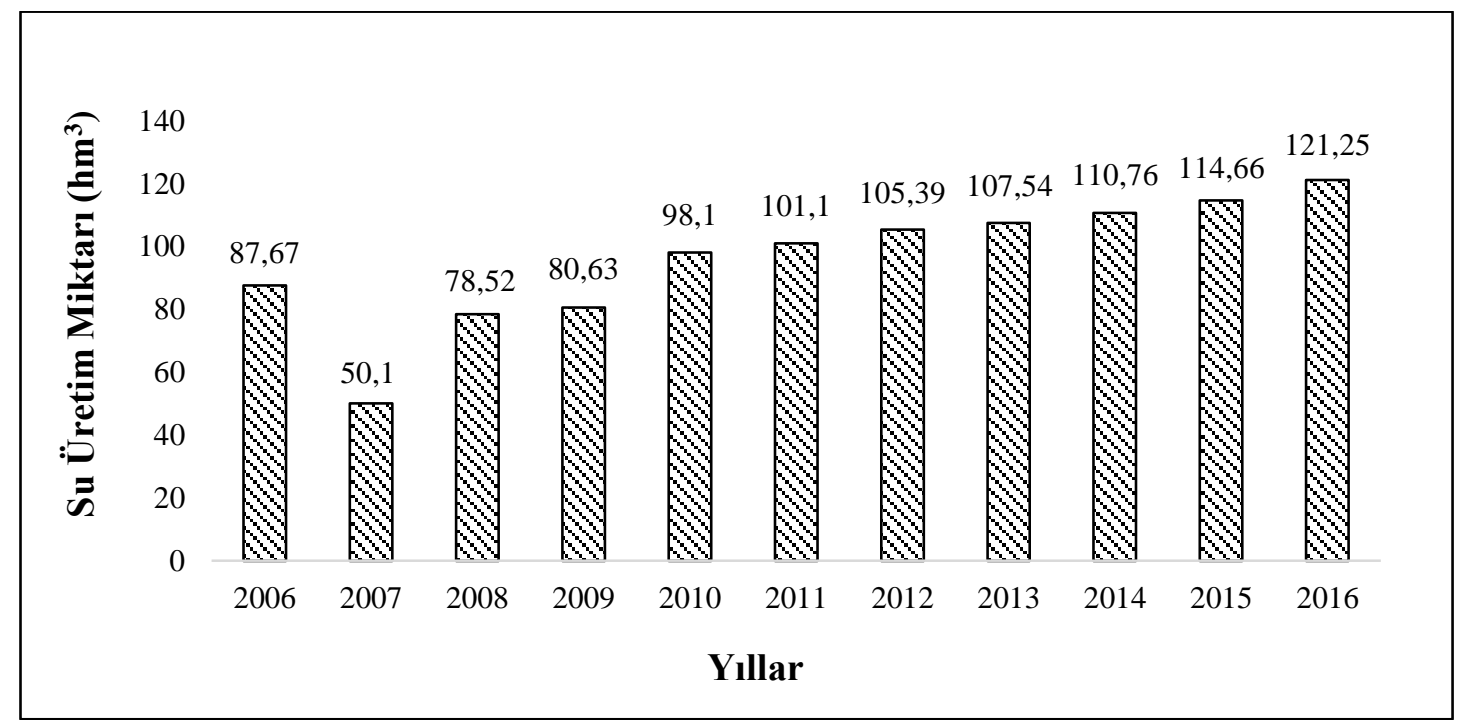

\section{Sekil 3:}

Bursa ilinin yıllara bağlı su üretim miktarları $\left(\mathrm{hm}^{3}\right)$

Bursa'nın su üretim miktarı yıllara bağlı ortalama $97 \mathrm{hm}^{3}$ olarak hesaplanmıştır. Şekil 3 incelendiğinde 2006-2016 periyodu içerisinde her yıl ağırlıklı olarak su üretimi artmasına rağmen, 2007 y1lında yaşanan kuraklık nedeniyle bir düşüş olduğu görülmektedir.

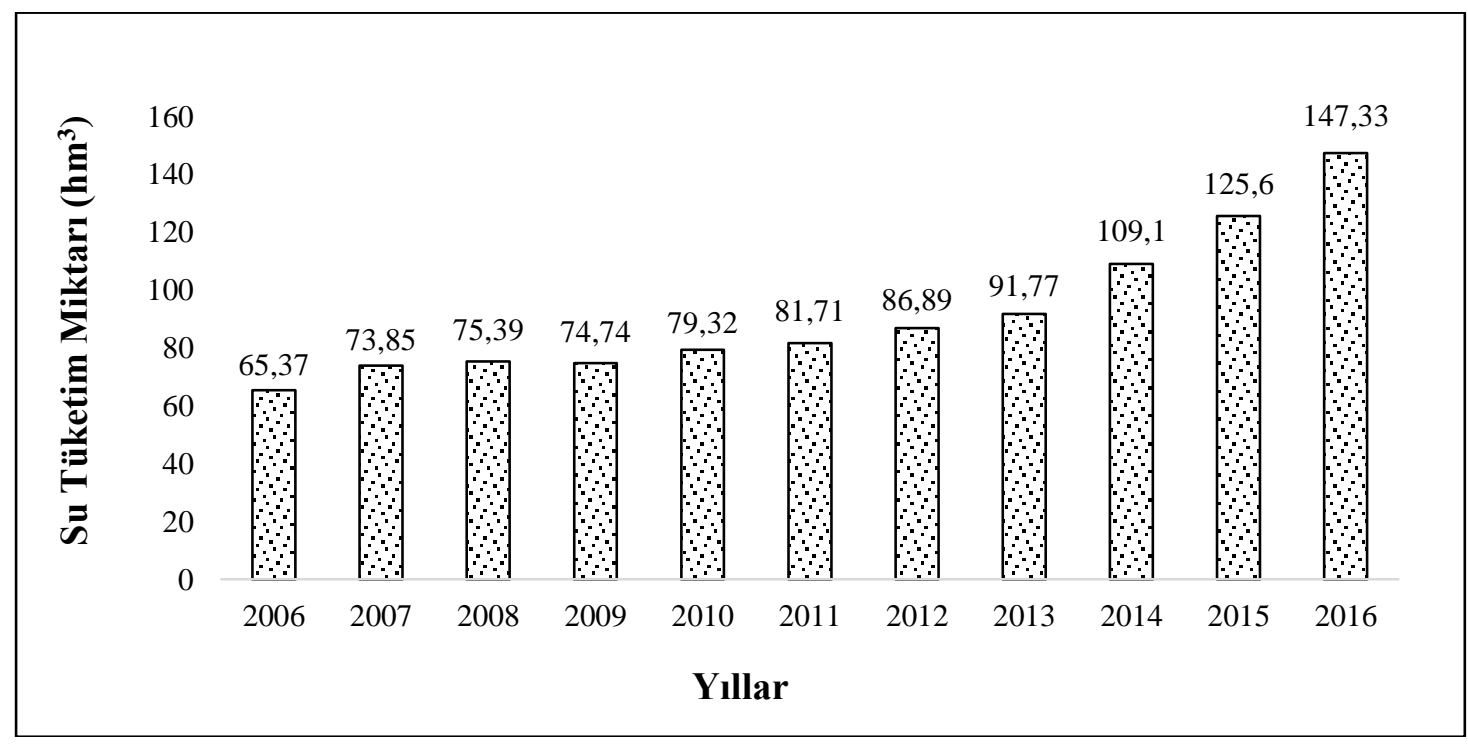

Bursa ilinin yıllara bağll su tüketim miktarları $\left(\mathrm{hm}^{3}\right)$

Bursa'nın su tüketim miktarı yıllara bağlı ortalama $91 \mathrm{hm}^{3}$ olarak hesaplanmıştır. İlin su ihtiyacı son 10 yıl içerisinde yaklaşık olarak $85 \mathrm{hm}^{3}$ artmıştır (Şekil 4). Bu değerler incelendiğinde nüfus ile doğru orantılı şekilde su ihtiyacının dolayısıyla su kaynakları kullanımının hızla arttığı görülmektedir.

2006-2014 yılları arasında üretilen su miktarları ile tüketilen su miktarları kıyaslandı̆̆ında, su kaynaklarının ilin su ihtiyacını karşılamakta olduğu görülmüştür. Ancak 2015-2016 yılları arasında ise üretilen su miktarlarının tüketilen su miktarlarından az olması ilin su kaynaklarının ihtiyacı karşılamada yetersiz kaldığını göstermektedir (Anonim, 2017c). 


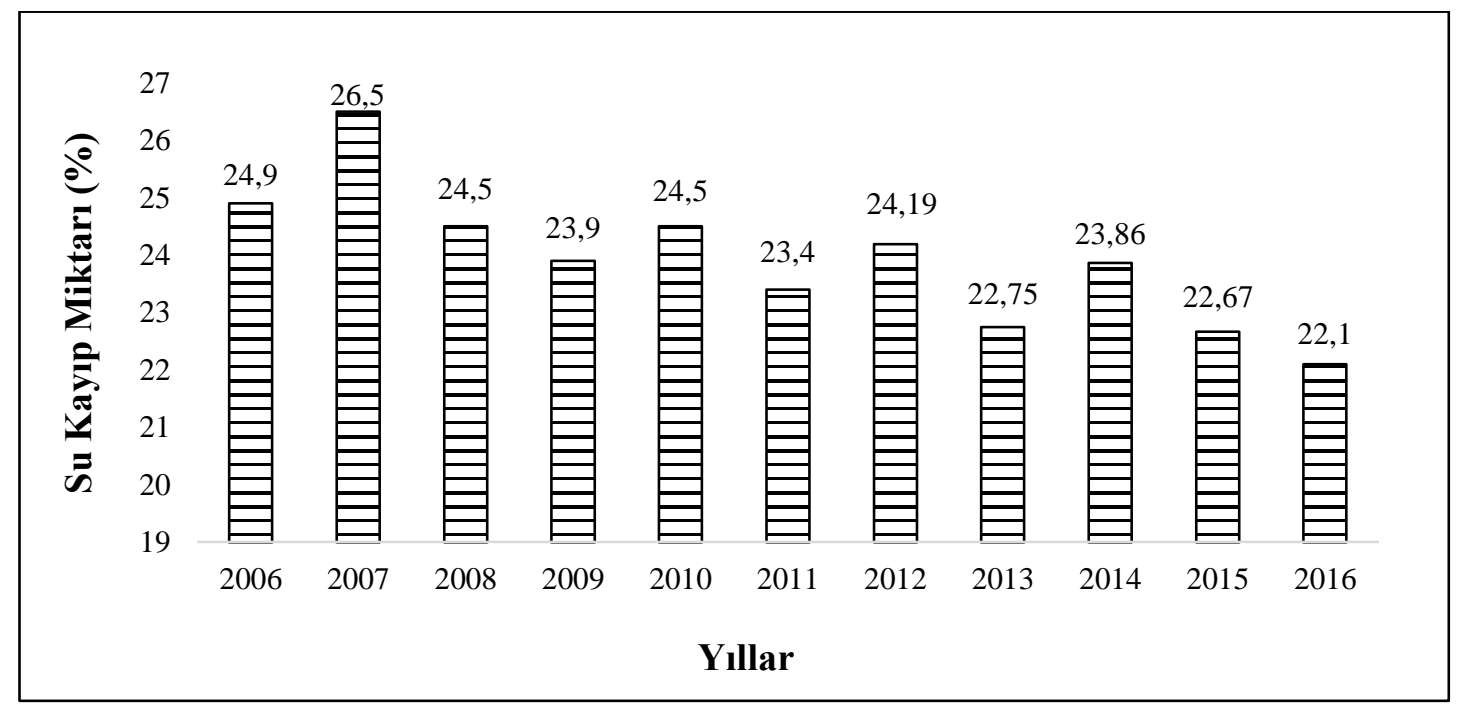

Şekil 5:

Bursa ilinin yıllara bağlı kayıp su miktarları (\%) (Anonim, 2017c)

Bursa ilinin yıllara bağlı kayıp su miktarları Şekil 5'te verilmiştir. Kayıp su miktarlarına bakıldığında Bursa'da çok büyük bir salınım olmadığı, kayıp oranının yaklaşık \%23 civarında bulunduğu görülmektedir. Son yıllarda kayıp su oranının $\% 22$ seviyesine kadar düşürülmesinde içme suyu hatlarında gerçekleştirilen bakım ve yenileme çalışmaları ile kanalizasyon hatlarında yapılan yağmur suyu ve kanal hatlarının ayrılmasının etkili olduğu düşünülmektedir.

Su kaynaklarının kullanımı bölgesel faaliyetlere göre değişmekte olup, su kirliliğine neden olan faktörlerde değişim göstermektedir. Bursa ili yüzeysel su kaynaklarının temel kirletici faktörleri Şekil 6'da verilmiştir. Bu faktörler evsel atıksu, evsel katı atık, endüstriyel atıksu ve zirai uygulamalar olarak 4 ana grupta toplanabilir. Kirletici faktörlerden evsel atıksuların tüm su kaynaklarını, endüstriyel atıksular ile tarımsal alanda kullanılan zirai ilaç ve gübrelerin Karsak ve Kaplıkaya dereleri dışındaki tüm dereleri, evsel katı atıkların ise özellikle Nilüfer ve Göksu derelerini kirlettiği Şekil 6'da görülmektedir.

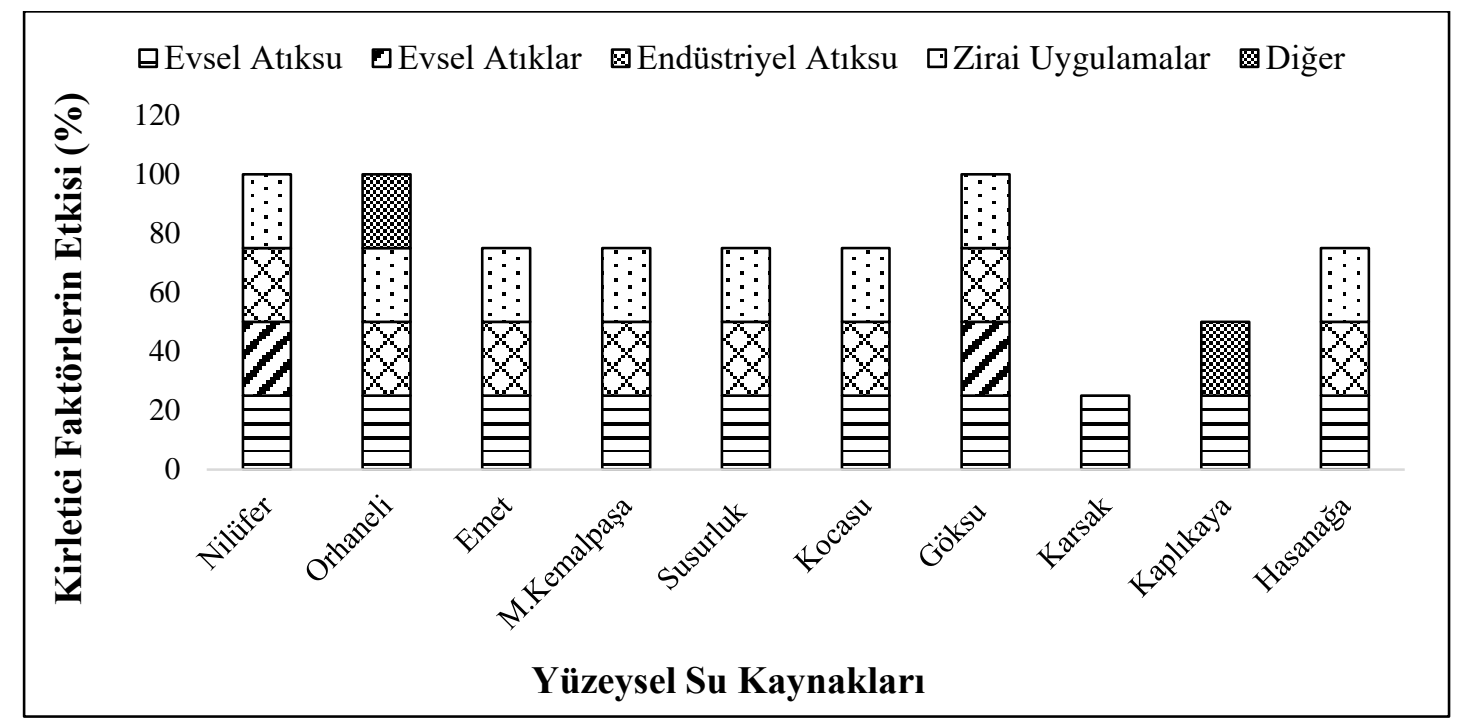

Sekil 6:

Bursa ili yüzeysel su kaynaklarının temel kirletici faktörleri (\%)(Anonim, 2010;Anonim, 2017c) 
Bursa ili yeraltı su kaynaklarının temel kirletici faktörleri Şekil 7'de verilmiş olup, 273 $\mathrm{hm}^{3} / \mathrm{y}$ 1l kapasiteye sahip yeraltı su kaynaklarını kirleten en önemli faktörlerin evsel atıklar ve endüstriyel atıksular olduğu görülmektedir. İlave olarak, kırsal kesimlerde zirai uygulamalar ve hayvancılık, kıyı kesimlerde ise deniz suyu girişimi su kaynaklarının kirlenmesine neden olmaktadir.

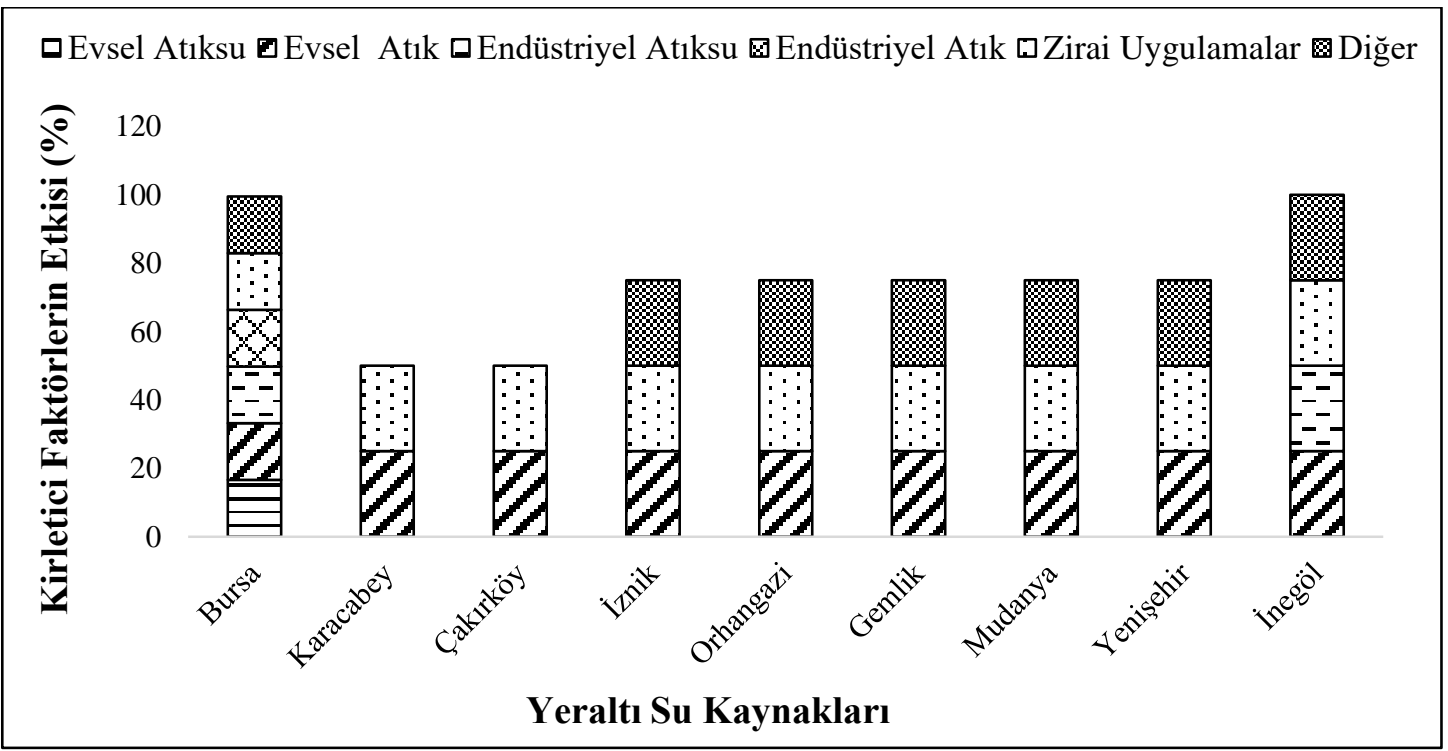

Sekil 7:

Bursa ili yeraltı su kaynaklarının temel kirletici faktörleri (\%)(Anonim, 2017a;Anonim, 2017c)

\subsection{Anket Çalışması}

Bursa ili su kaynaklarında mevcut su kirliliğine yönelik Çevre ve Şehircilik Bakanlığı'nın Türkiye Çevre Sorunları ve Öncelikleri Değerlendirme Raporu'na göre Bursa'nın birinci öncelikli sorununun su kirliliği olduğu belirtilmektedir (Anonim, 2017a). Bu nedenle kentsel su yönetimi kavramı çerçevesinde doğru ve uygulanabilir planlamaların yapılabilmesi için, çevre ve çevre koruma alanında hizmet veren, Çevre ve Şehircilik İl Müdürlügü, Devlet Su İşleri Bölge Müdürlüğü, Orman ve Su İşleri Bölge Müdürlügü, Bursa Su ve Kanalizasyon İdaresi (BUSKİ), Büyükşehir Belediyesi, Osmangazi Belediyesi, Yıldırım Belediyesi, Nilüfer Belediyesi'nde görev alan 200 yöneticiye anket çalışması uygulanmıştır. Anket çalışması ile yöneticilerin görüşlerinin alınmasındaki temel amaç, plan ve projelerin her adımında kamu kurumlarının bulunmasını gerektiğinin vurgulanmasıdır. Yönetici görüşlerinin alındığı anket çalışması kişisel bilgiler, suyun bilinçli tüketimi ve geri kazanımına yönelik 3 bölümden oluşmakta, toplam 38 soru içermektedir. Bu çalışmada bu konu ile doğrudan ilgili olduğu düşünülen ve aşağıdaki Tablo 2'de verilen soruların değerlendirmesi yapılmıştır. 
Tablo 2. Anket Soruları

\section{$\underline{\text { Suyun Bilinçli Tüketimine Yönelik Sorular }}$}

- Sizce il veya ilçenizdeki su kaynakları kullanım ihtiyacınızı karşılar düzeyde midir?

$\square$ Evet $\square$ Hayır

- Kurumunuzda içme suyu olarak tercihiniz nedir?

$\square$ Şebeke Suyu $\square$ Şişe Suyu $\square$ Kaynak Suyu $\square$ Su Arıtım Sistemi

- Sizce ileriye yönelik Bursa ili için su kıtlığı bir problem teşkil edebilir mi?

$\square$ Evet $\square$ Hayır

- Sizce aşağıdakilerden hangileri su kıtlığına çözüm olabilir?

$\square$ Yeni Su Kaynakları $\square$ Suyun Etkin Kullanımı

$\square$ Suyun Geri Kazanımı ve Tekrar Kullanımı $\square$ Yağmur Suyundan İstifade Edilmesi

- Kurumunuzca su kullanımına yönelik mevzuat birimlerinin yeterli duruma getirilmesi için hangi çalışmalar yapılmalıdır?

$\square$ Yeni Stratejik Planlama Çalışmaları $\square$ Mevzuat Kapsamının Genişletilmesi Diğer Ülkelerin Mevzuatı İncelenmeli $\square$ Diğer (.......)

- Sizce il veya ilçenizdeki su kaynakları kullanım ihtiyacınızı karşılar düzeyde midir?

Yöneticilerin çalıştıkları il veya ilçedeki su kaynaklarının yeterliliği ile ilgili soruya anket katılımcılarının \%93,4'ü evet yanıtını verirken, \%7'si hayır yanıtını vermiştir (Şekil 8). Verilen yanıtlar neticesinde ilin su kaynaklarının yönetiminde söz sahibi olan kurumlara [Devlet $\mathrm{Su}$ İşleri Bölge Müdürlüğü (\%100), Orman Su İşleri Bölge Müdürlüğü (\%100) gibi] göre mevcut su kaynaklarının Bursa'nın kullanım ihtiyacını tam olarak karşılar düzeyde olduğu görülmüştür.

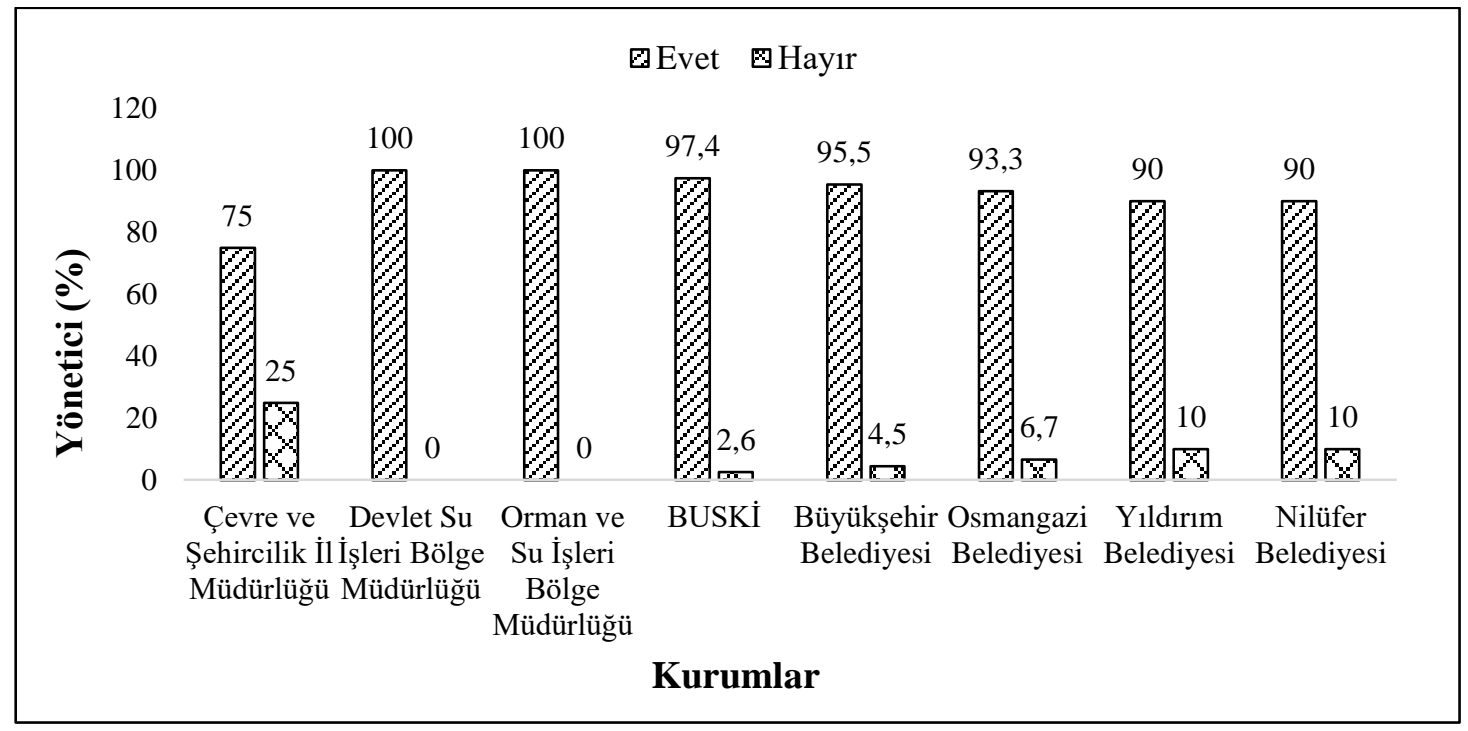

Şekil 8:

Su kaynaklarının yeterliligine yönelik yanıtlar

- Kurumunuzda içme suyu olarak tercihiniz nedir?

Ankete katılan yöneticilere çalıştıkları kurumlarda içme suyu tercihleri sorulduğunda, $\% 30,5$ 'i şebeke suyu, \%65,5'i şişe suyu, \%7,5'i kaynak suyu ve \%2,5'inin su arıtım sistemi yanıtını vermiş oldukları Şekil 9'da gösterilmektedir. Kurumların içme suyu tercihlerini 
etkileyen faktörlerin, şebeke ve şişe suyu için güvenlik, kaynak suyu ve su arıtma sistemi için ise altyapı hizmetleri olduğu anketin değerlendirilmesi neticesinde kanaatine varılmıştır.

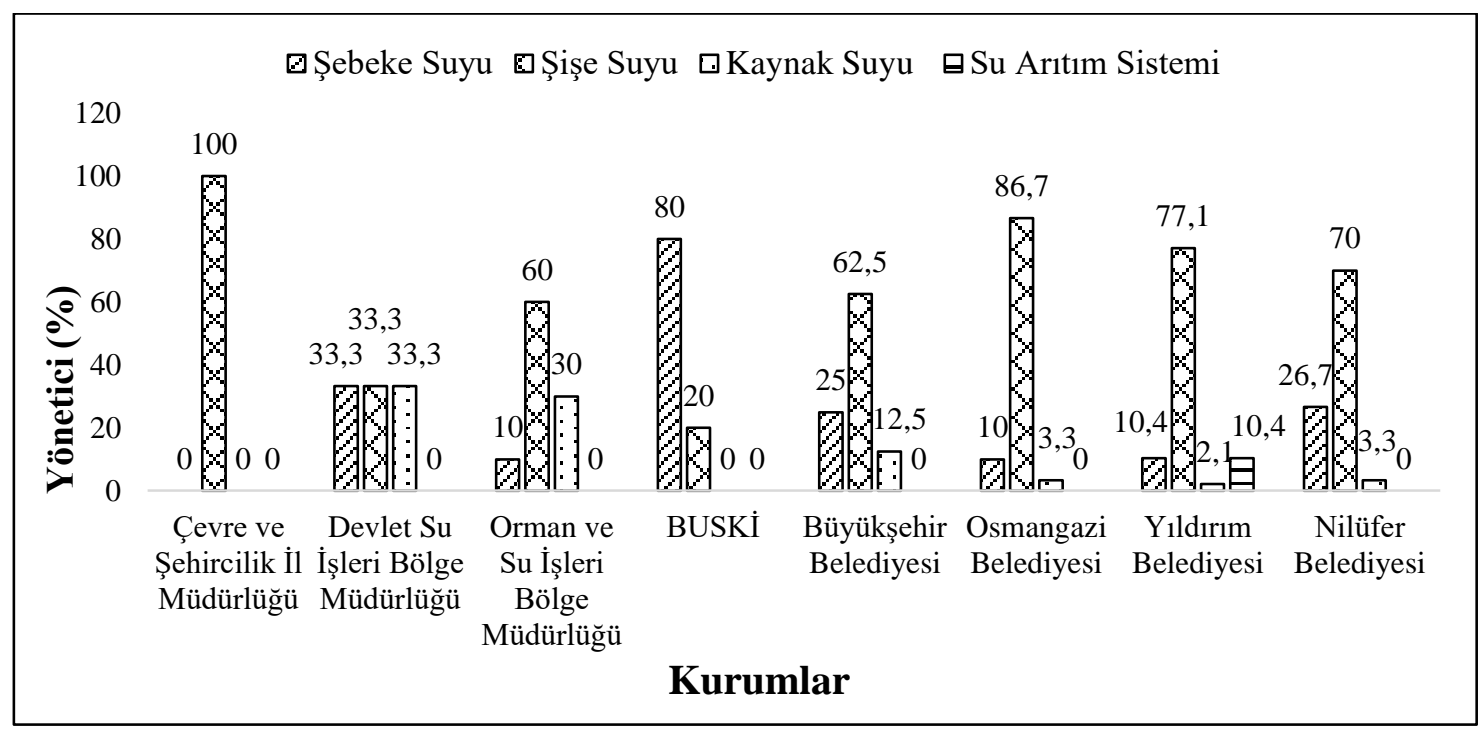

Şekil 9:

Kurumlardaki içme suyu tercihine yönelik yanıtlar

- Sizce ileriye yönelik Bursa ili için su kutlığı bir problem teşkil edebilir mi?

Yöneticilere ileriye yönelik Bursa ili için su kıtlığının bir problem teşkil edip etmediği sorulduğunda, anket katılımcılarının \%61,5'inin evet, \%38,5'inin hayır yanıtını verdiği Şekil 10 'da görülmektedir. Bu durumda ilin su kaynaklarının planlamasında yetki sahibi olan [Devlet Su İşleri Bölge Müdürlüğü $(\% 33,3)$, BUSKİ $(\% 34,4)$ gibi] kamu kurumları tarafından mevcut ve ileriye yönelik su kıtlığı problemi yaşanmayacağı, kaynaklarını kullanımında ve denetiminde yetki sahibi kurumlar [Belediyeler (\%71,1), Çevre ve Şehircilik İl Müdürlüŭü (\%75) gibi] tarafından ise su kıtlı̆̆ problemi yaşanabileceği belirtilmiştir.

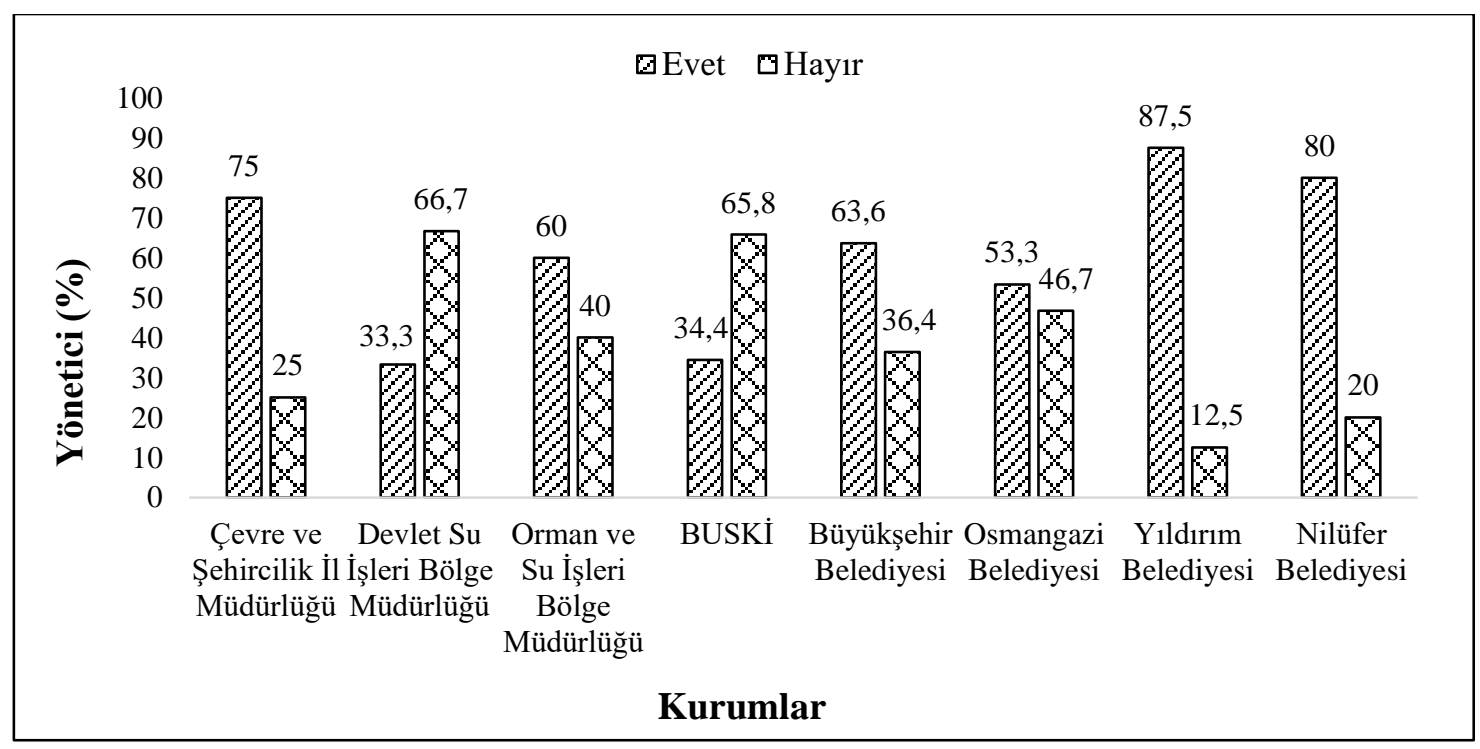

Şekil 10:

Bursa ilinde su kutllğg problemine yönelik yanıtlar 
- Sizce aşağıdakilerden hangileri su kıtllğına çözüm olabilir?

Anket katılımcılarına su kıtlığına karşı çözüm önerileri sorulduğunda, yöneticilerin \%36,4'ü suyun etkin kullanımı, \%33,4'ü suyun geri kazanımı ve tekrar kullanımı, \%20,2'si yağmur suyundan istifade edilmesi, \%10,1'i ise yeni su kaynakları yanıtlarını tercih etmiş̧tir (Şekil 11). Bu durum yöneticilerin önceliğinin mevcut su kaynaklarının sürdürülebilir kullanımına vurgu yaptığını göstermektedir.

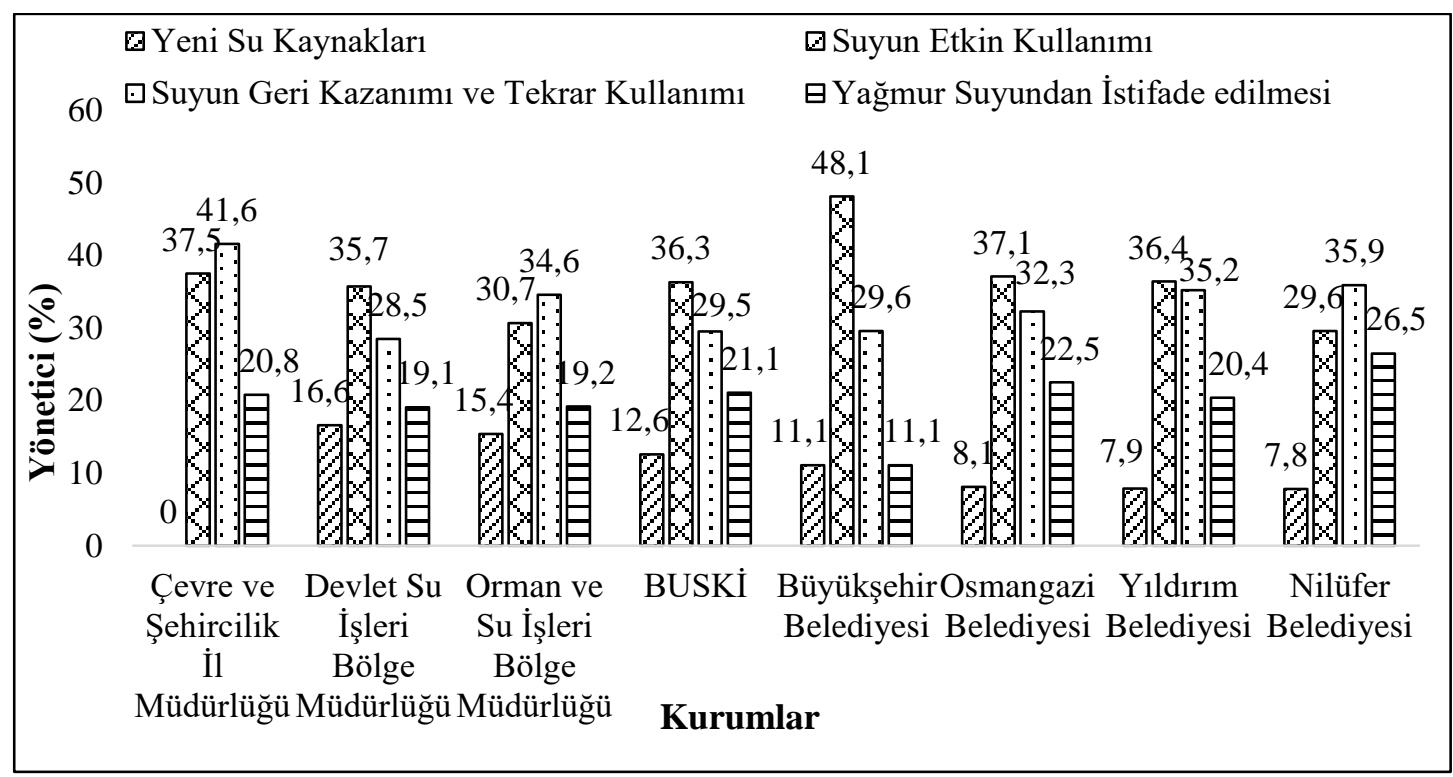

Şekil 11:

Su kitlı̆̆ı çözüm önerilerine yönelik yanıtlar

- Kurumunuzca su kullanımina yönelik mevzuat birimlerinin yeterli duruma getirilmesi için hangi çalışmalar yapılmalıdır?

Yöneticilere kurumlarında su kullanımına yönelik mevcut mevzuatın iyileştirilmesi amacıyla yapılabilecek çalışmalar sorulduğunda, katılımcıların \%37,9'u yeni stratejik planlama çalışmalarına ihtiyaç olduğu, \%35,4'ü mevzuat kapsamının genişletilmesi gerektiği, \%21,7'si ise diğer ülkelerin mevzuatı incelenmeli yönünde yanıt vermiştir (Şekil 12). Kurumların mevzuat eksikliklerin yeterli duruma getirilmesi için yöneticilerin görüşlerine göre, kurumların yetki alanları dikkate alınarak iyileştirme çalışmaları yapılması neticesine ulaşılmıştır. 


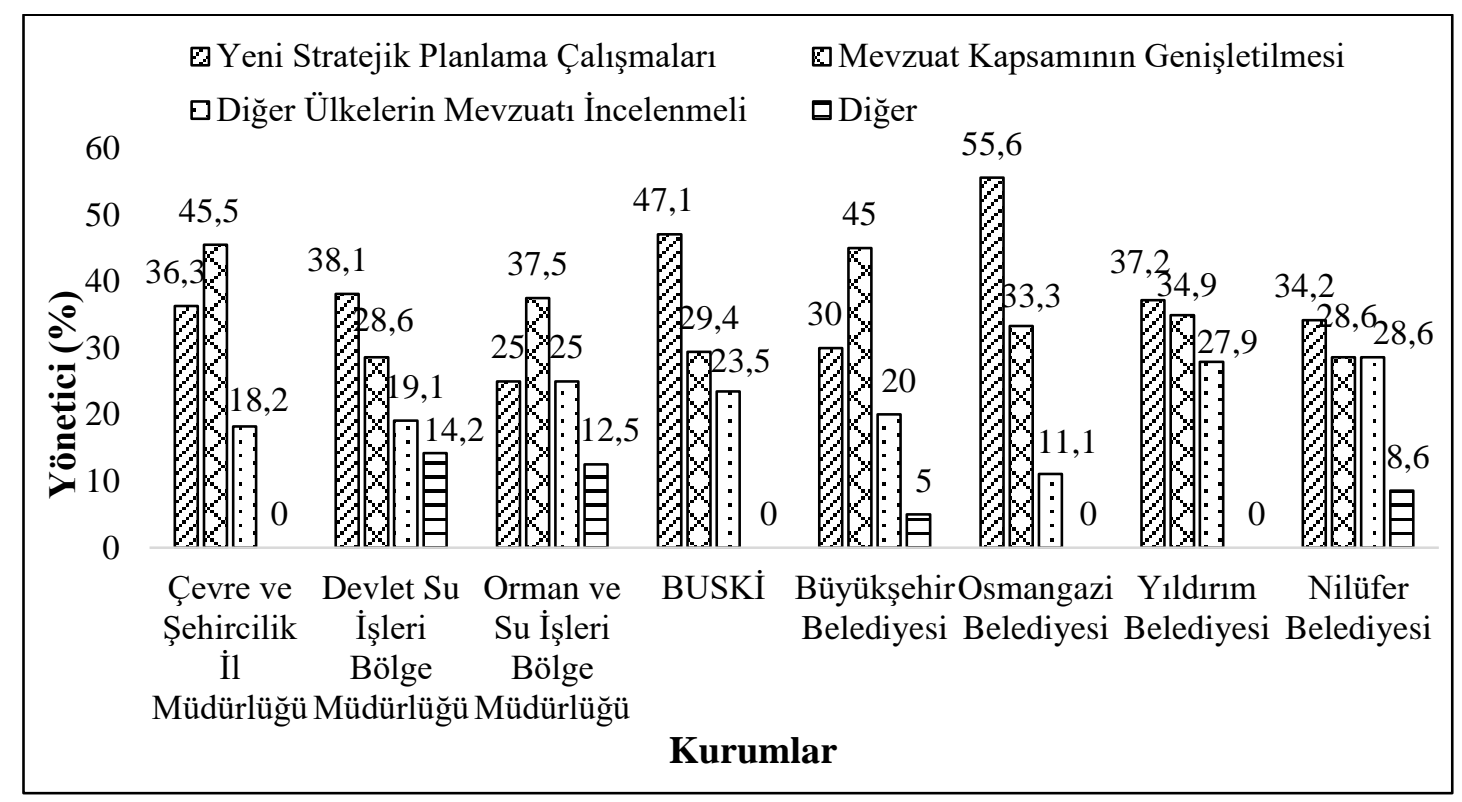

Şekil 12:

Mevzuat eksiklikleri çözüm önerilerine yönelik yanıtlar

\section{SONUÇ VE ÖNERILLER}

$\mathrm{Su}$ kaynaklarına olan ihtiyacın sürekli olarak artması, miktar ve kalitesinin değerlendirilmesi amacıyla bu çalışmada Bursa'nın su kaynakları için, 2006-2016 yılları arasındaki 10 yıllık periyotta su üretim, tüketim ve kayıp oranları incelenmiştir. Çalışma neticesinde 2014 yılına kadar mevcut durum için su kaynaklarının su ihtiyacını karşıladı̆̆ 2015-2016 yıllarında ise su tüketim miktarlarının artmış olması, su kaynaklarının yetersiz kalmaya başladığı ve bununla birlikte su kaynaklarında su kirliliğinin de önemli bir sorun haline geldiği görülmüştür. İl sınırı içerisinde su kirliliğine sebep olan temel kirletici faktörlerin değerlendirildiği bu çalışmada, su kirliliğinde öncelikli kirletici kaynağın atıksular, diğer nedenlerin ise evsel ve endüstriyel nitelikli katı atıkların yüzeysel kaynaklarda birikimi, endüstriyel tesislerin atıksu bertaraf sorunu, Organize Sanayi Bölgelerinden kaynaklanan atıksuların arıtılmasında ileri arıtma teknolojilerinin kullanılmaması olarak ortaya konmuştur. İlave olarak zirai ilaçların ve gübrelerin tarımda yanlış kullanımı da su kirliliğini arttıran faktörler arasındadır (Anonim, 2017a). Bu faktörlere karşı alınabilecek önlemlerden bazıları Tablo 3'de önerilmiştir.

Tablo 3. Bursa ili su kaynaklarında kirlilikle mücadele önerileri

\begin{tabular}{|c|c|c|c|c|}
\hline Öneriler & Akarsu & $\begin{array}{c}\text { Yeraltı } \\
\text { Suyu }\end{array}$ & Göl & Deniz \\
\hline $\begin{array}{c}\text { Kanalizasyon şebekesinin yapılması ya da } \\
\text { yenilenmesi }\end{array}$ & $\mathrm{X}$ & $\mathrm{X}$ & $\mathrm{X}$ & $\mathrm{X}$ \\
\hline $\begin{array}{c}\text { Arıtma tesisi /deniz deşarjı /depolama alanlarının } \\
\text { yapılması }\end{array}$ & $\mathrm{X}$ & $\mathrm{X}$ & $\mathrm{X}$ & $\mathrm{X}$ \\
\hline $\begin{array}{c}\text { Yerleşim merkezinde fosseptik kullanılması } \\
\text { Zirai ilaç ve gübrenin aşırı ve yanlış kullanımının } \\
\text { önlenmesi }\end{array}$ & $\mathrm{X}$ & $\mathrm{X}$ & $\mathrm{X}$ & $\mathrm{X}$ \\
\hline Yönetmelikler çerçevesinde denetim yapılması & $\mathrm{X}$ & $\mathrm{X}$ & $\mathrm{X}$ & $\mathrm{X}$ \\
\hline $\begin{array}{c}\text { Deniz araçlarının atıklarını boşaltabilmeleri için } \\
\text { uygun yerlerin hazırlanması }\end{array}$ & & & & $\mathrm{X}$ \\
\hline Endüstriyel atıksular için deşarj izinlerinin alınması & $\mathrm{X}$ & & $\mathrm{X}$ & $\mathrm{X}$ \\
\hline Toplumun bilgilendirilme ve bilinçlendirilmesi & $\mathrm{X}$ & $\mathrm{X}$ & $\mathrm{X}$ & $\mathrm{X}$ \\
\hline
\end{tabular}


$\mathrm{Bu}$ çalışmada ayrıca, sürdürülebilir kentsel su yönetiminde planlama ve uygulama adımlarının doğru şekilde oluşturulabilmesine yönelik bazı kamu kurumları yöneticilerin görüşleri de alınmıştır. Bu kapsamda yapılan anket sorularına alınan yanıtlar, su kaynaklarının sürdürülebilir kullanımına yönelik uygun stratejileri belirlemek için önem arz etmektedir.

Çevre ve çevre koruma alanında hizmet veren 8 kamu kurumunda görev alan 200 yöneticiye uygulanan anket soruları içinden bu çalışmayla doğrudan ilgili 5 soru seçilip, değerlendirilmiştir. Katılan yöneticilere göre Bursa ilinin su kaynaklarının mevcut durumda ihtiyacı karşılamakta olduğu $(\% 93,4)$, seçilen kurumlarda içme suyu olarak daha çok şişe suyunun $(\% 65,5)$ tercih edildiği ve gelecekte ise Bursa ilinde bir su sıkıntıs1 yaşanabileceği (\%61,5) yanıtları elde edilmiştir. Edinilen bilgiler, su kaynaklarının planlanmasına yönelik çalışmaların her adımında karar verme yetkisi bulunan yönetici görüşlerine yer verilmesi gerektiği ve ileriye yönelik sürdürülebilirliğin sağlanabilmesi için ilde kentsel su yönetiminin uygulanması gerektiği düşünülmektedir. Ayrıca ilgili kurumlar tarafından gerekli planların hazırlanması aşamasında SWOT (güçlü noktalar, zayıf noktalar, tehditler, firsatlar) analizinin yapılması ve doğru şekliyle uygulanması gerekmektedir.

$\mathrm{Bu}$ amaçla kapsamlı bir SWOT analizi yapılmadan önce, doğru bir planlama yapılabilmesine zemin hazırlamaya yönelik örnek bir akış diyagramı Şekil 13'te sunulmuştur. Örnek akış diyagramına göre, bu çalışmada yapılan anket ve benzeri çalışmalardan elde edilen bilgilerin raporlanması, akabinde ilgili kurum ile verilerin paylaşılması, kurum tarafından yapılabilecek planlama çalışmalarının belirlenmesi aşamasında, ilgili kurum tarafından değerlendirmesi ile mümkün olabilecektir.

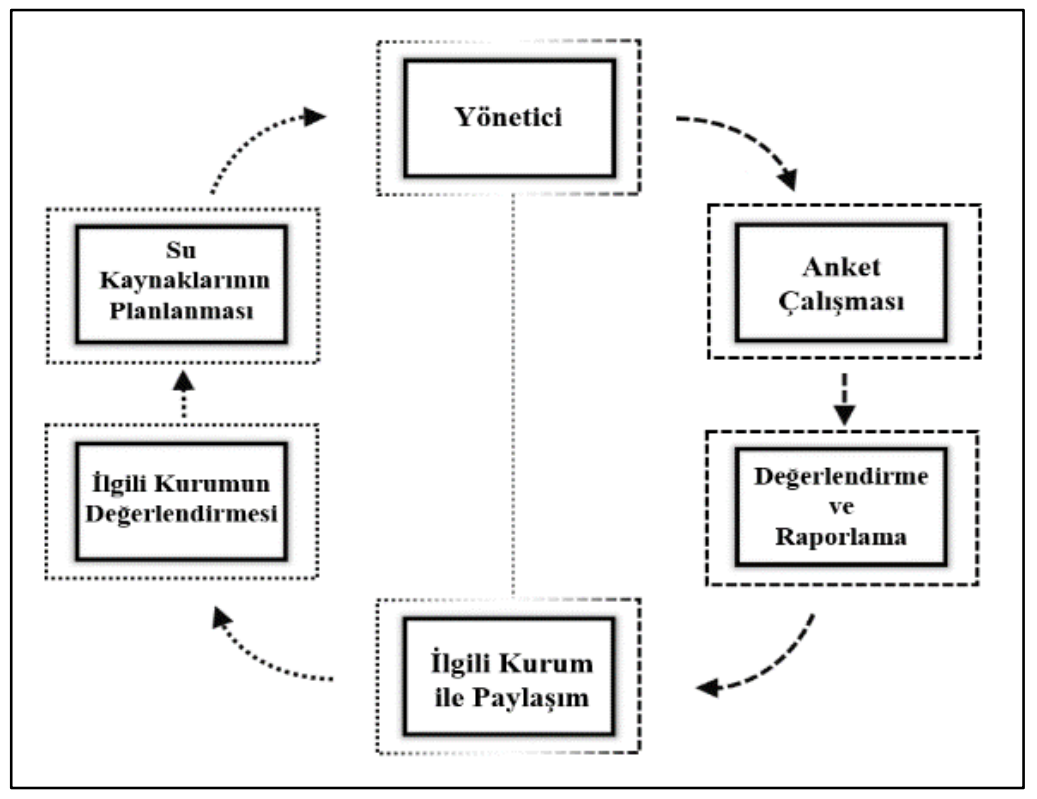

Şekil 13:

Sürdürülebilir kentsel su yönetiminin planlanmasında örnek akış diyagramı

Önerilen örnek akış diyagramına benzer diyagramların çeşitliliğinin ve sayısının arttırılması ile sürdürülebilirlik anlayışına dayanan kentsel su yönetiminin oluşturulması, suya gereken önemin verilmesi ve su kaynaklarında sürdürülebilirliğin temin edilmesinin daha kolay sağlanabileceği düşünülmektedir. 


\section{KAYNAKLAR}

1. Akal Solmaz S.K., Yalılı Kılıç M., Üstün G.E., (2011) Bursa İli Su Kaynaklarının Mevcut Durumunun Değerlendirilmesi, 1.Klyı Bölgelerinde Çevre Kirliliği ve Kontrolü, 17-20 Kasım 2011, Tekirdağ

2. Anonim (2010) Türkiye Çevre Sorunları ve Öncelikleri Değerlendirme Raporu 2010

3. Anonim (2015) II. Marmara Denizi Sempozyumu, İstanbul

4. Anonim (2016a) Çevre ve Şehircilik Bakanlığı 2016 İl Çevre Durum Raporu

5. Anonim (2016b) Orman ve Su İşleri Bakanlığı 2016 Nilüfer Çayı Alt Havza Planı

6. Anonim (2017a) Türkiye Çevre Sorunları ve Öncelikleri Değerlendirme Raporu 2017

7. Anonim (2017b) Bursa Büyükşehir Belediyesi Sahil Hizmetleri 2017 Raporu

8. Anonim (2017c) Bursa Su ve Kanalizasyon İdaresi

9. Anonim (2018) Türkiye İstatistik Kurumu 2017 İller Nüfus Bilgileri

10. Araujo R.S. ,Alves M.G., Melo M.T.C., Chrispim Z.M.P., Mendes M.P. ,Junior G.G.S. (2015) Water Resource Management: A Comparative Evaluation of Brazil, Rio De Janeiro, The European Union, and Portugal, Science of the Total Environment, 511, 815-828. doi:10.1016/j.scitotenv.2014.11.098

11. Corcoles J.I., Juan J.A., Ortega J.F., Tarjuelo J.M., Moreno M.A. (2010) Managament Evaluation Of Water Users Associations Using Bencmarking Techniques, Agriculture Water Management, 98, 1-11. doi:10.1016/j.agwat.2010.07.018

12. Gao H., Wei T., Lou I., Yang Z., Shen Z., Li Y. (2014) Water Saving Effect on İntegrated Resource Management, Resource, Conservation and Recycling, 93, 50-58. doi:10.1016/j.resconrec.2014.09.009

13. Hoek J.P.,Fooij H., Struker A., (2016) Wastewater as a resource: Strategies to recover resource from Amsterdam's wastewater, Resources, Conservation and Recycling, 113, 5364. doi:10.1016/j.resconrec.2016.05.012

14. Hu X., Xiong Y.,Li Y., Wang J., Li F. (2014) Integrated Water Resources Management And Water Users'associations In The Arid Region Of Northwest China: A Case Study Of Farmers'Perceptions, Journal of Environmental Management, 145, 162-169. doi:10.1016/j.jenvman.2014.06.018

15. Kolokytha E.G., Mylopoulos Y.A., Mentes A.K. (2002) Evaluating Demand Management Aspects of Urban Water Policy-A Field Survey in The City of Thessaloniki, Greece, Urban Water, 4, 391-400. doi:10.1016/S1462-0758(02)00024-9

16. Meriç, B.T. (2004). Su kaynakları yönetimi ve Türkiye, Jeoloji Mühendisliği Dergisi, 28-1, 27-38.

17. Petroulias N., Foufeas D., Bougoulia E., (2016) Estimating Water Losses and Assessing Network Management İntervention Scenarios: The Case Study of The Water Utility of The City of Drama in Greece, Procedia Engineering, 162, 559-567. doi:10.1016/j.proeng.2016.11.101

18. Ross A. (2017) Speeding The Transition Towards Integrated Groundwater and Surface Water Management in Australia, Journal of Hydrology, 567, e1-e10. doi:10.1016/j.jhydrol.2017.01.037 
19. Rygaard M., Godskesen B., Jorgensen C., Hoffmann B., (2014) Holistic Assesment Of A Secondary Water Supply For A New Development İn Copenhagen, Denmark, Science of the Total Environment, 497-498, 430-439. doi: 10.1016/j.scitotenv.2014.07.078

20. Teksoy A., Erol Nalbur B., Akal Solmaz S.K. (2017) Bursa İlinin Su ve Atıksu Potansiyelinin Değerlendirilmesi, Uludă̆ University Journal of The Faculty of Engineering, 22-1,115-124. doi:10.17482/uumfd.309452

21. Yalılı Kılıç M., Akal Solmaz S.K., Çiner F. (2013) Kentsel Su Yönetiminde Su Kullanıcısının Önemi, 3. Uluslararası Bursa Su Kongresi, 22-24 Mart 2013, Bursa.

22. Yalılı Kılıç M., Akal Solmaz S.K., Üstün G.E., Kestioğlu K., (2011) Su Temini Yönünden Bursa İli Su Kaynaklarının Bugünü ve Geleceği, Blacksea International Environmental Symposium, 25-29 Ağustos 2008, Giresun.

23. Yalılı Kılıç, M. ve Akal Solmaz, S.K. (2016) Su Kaynakları Yönetiminde Sürdürülebilirlik: Bursa İli Örneği, International Symposium of Water and Wastewater, 26-28 Ekim 2016, Malatya.

24. Yalılı M., Akal Solmaz S.K., Kestioğlu K. (2006) Bursa İli Su Kaynakları Potansiyeli ve Su Kullanıc1 Faktörü, Uludağ University Journal of The Faculty of Engineering, 11-2,1-13. 